\title{
Otolaryngology Residents' Attitudes, Experiences, and Barriers Regarding the Medical Research
}

\author{
Original Investigation $>$ (1) Hülya Eyigör ${ }^{1}$, (1) Cüneyt Orhan Kara² \\ ${ }^{1}$ Department of Otorhinolaryngology, Antalya Training and Research Hospital, University of Health Sciences Turkey, \\ Antalya, Turkey \\ ${ }^{2}$ Department of Otorhinolaryngology, Pamukkale University Faculty of Medicine, Denizli, Turkey
}

Abstract

This study was presented in the online Turkish Congress on Otolaryngology-Head and Neck Surgery held between November $26^{\text {th }}$ and November $28^{\text {th }} 2020$.

\section{ORCID ID of the authors:}

H.E. 0000-0001-5317-431X; C.O.K. 0000-0003-2219-4283.

Cite this article as: Eyigör $\mathrm{H}$, Kara CO. Otolaryngology Residents' Attitudes, Experiences, and Barriers Regarding the Medical Research. Turk Arch Otorhinolaryngol 2021;59(3):215-22.

Corresponding Author: Hülya Eyigör; hulya.eyigor@sbu.edu.tr

Received Date: 17.04.2021 Accepted Date: 29.08.2021

Content of this journal is licensed under a Creative Commons Attribution 4.0 International License. Available online at www.turkarchotolaryngol.net
Objective: It was aimed to investigate the attitudes, experiences, and barriers towards scientific research among otolaryngology residents in Turkey.

Methods: Anonymous data were collected via an online survey. The demographic characteristics and experience in scientific research were investigated in the first section of the survey. The attitudes of participants towards scientific research and the barriers to the scientific research were examined in the second section of the survey using 17 items.

Results: The present study involved 119 otolaryngology residents continuing their education. It was determined that $68.1 \%$ of participants think that "participating in scientific research" is a part of otolaryngology training. In the present study, it was shown that the residents having journal club hours in clinics on regular basis participated in various steps of scientific research projects $(\mathrm{p}<0.05)$. Residents stated that they participated in the "literature review" stage of the preparation of a scientific publication (mean value of $2.58 \pm 1.88$ ) most and in "verbal presentation in a congress" least (mean value of $0.74 \pm 1.44$ ). It was determined that $80.7 \%$ of participants have not attended in any training on scientific research. It was found that the residents receiving structured scientific research training participated more in steps of scientific research projects which was statistically significantly $(\mathrm{p}<0.05)$.

Conclusion: In our country, otolaryngology residents are very enthusiastic about having research education and participating in researches. However, residency students frequently have time deficiency, lack of knowledge-skill, and lack of financial support. Dedicated time should be allocated for research training and practice in specialty programs. Journal club activities should be organized on regular basis and integrated with research education. On the other hand, the scholarly activities of residents should be supported by means of various countrywide educational activities on research training.

Keywords: Otorhinolaryngology, scientific research, resident, research education, community survey, educational activities 


\section{Introduction}

For a successful scientific research, having knowledge on writing a manuscript and on technical subjects such as clinical study design, bias, confounders, and statistics is a must. Besides the curriculum, the research education in residency education can be improved by implementing the theoretical knowledge in a research project and by sharing the experiences of a mentor (1). In the entire world, scholarly activity is an essential component of otolaryngology residency training programs. In our country, however, the involvement of residency students in researches during their residency period originates for the first time from "Regulation on Medical Residency" in 1974 (2). The research component has been included first time in the Turkish Otolaryngology-Head and Neck Surgery Residency Core Curriculum published in 2012 (3). In this program, the research activities were identified as a learning tool and it was recommended for every resident to participate in a minimum of one research (except for the thesis study) during the residency period. In the section of cognitive learning, it was requested for the resident to plan and conduct a research and make a scientific presentation. In the following years, the Curricula and Standard Development System of the Council of Specialty in Medicine (TUKMOS) developed the current otolaryngology specialty curriculum (4). In this program, research is defined as "the process of designing a research on a subject solely by a student or with a team and, by determining the learning needs in this period, meeting these needs from any educational source". Research activity has been employed in medical residency education since 1974 but there is no study examining how successfully the research component has been implemented.

In the present study, it was aimed to determine the ear nose throat (ENT) residents' attitudes, experiences, and barriers in scientific research in Turkey, as well as the troubles they have experienced.

\section{Methods}

In the present study, it was planned to collect the data via an anonymous web-based survey. In the first step, a comprehensive literature review was performed by researchers and an item pool was established (5-8). Then, two researchers working in different institutions conducted interviews with ENT residents and the item pool was prepared by enriching with the items including the conditions of ENT residency in our country. And then, considering the simplicity and understandability of items, the preliminary corrections were made and the opinions of experts about the item pool were collected. The preliminary implementation of the survey, on which the experts had a consensus, was performed with 10 ENT residents asked to answer the draft items and it was confirmed that the items were understandable.
The first part of the survey includes the items examining the demographical characteristics (gender, type of hospital where they receive residency training, and years in residency education) and experience in the cognitive research field. Using 17 items in the second section of the survey with 5-point Likert scale, the participants were asked to assess the attitudes towards research and the barriers they face. The surveys were conducted online using Google ${ }^{\circledR}$ forms. Announcements were regularly performed through "Kanal KBB" online communication platform, in which ENT residents are members, and via training clinic supervisors in order for ENT residents to fill in the surveys. The online survey was kept accessible for the participants for a month between August $15^{\text {th }}$ and September $15^{\text {th }}$ 2020. Ethics committee approval was obtained from the Clinical Research Ethics Committee of Pamukkale University (08.01.2020/456).

\section{Statistical Analysis}

All the analyses were performed using IBM SPSS 23.0 package program (IBM Corp., Armonk, NY). Descriptive statistics were expressed as frequency and percentage for categorical variables and mean \pm standard deviation $(\mathrm{SD})$ for continuous variables. The relationships between categorical variables were analyzed using Fisher's Exact Test or Pearson's chi-square test. The difference between measurements in two groups was analyzed using Student's t-test. A two-sided p-value $<0.05$ was interpreted as statistically significant.

\section{Results}

The target sample size was determined to be 544 , the number of ENT residents actively continuing their education. In total, 119 (rate of participation is 21.8\%) ENT residents (woman: 35, man: 84) responded. Demographic characteristics of residents are presented in Table 1 . The mean age of volunteer participants was found to be $28.22 \pm 1.81$ years (min: 25 -max: 35). Seniorities of participants are 28 in the first year, 25 in the $2^{\text {nd }}$ year, 38 in the $3^{\text {rd }}$ year, 10 in the $4^{\text {th }}$ year, and 18 in the $5^{\text {th }}$ year. In order to compare the residents' participation in scientific researches and their attitudes with the core curriculum in ENT residency education, the seniorities of residents were examined by dividing in two ( $\geq 24$ months and $<24)$.

Comparison of research experience of residents by gender, type of hospital and residency training periods is presented in Table 2. From the aspect of gender, a statistically significant difference in favor of men was observed in preparing a method for scientific research $(\mathrm{p}=0.024)$. Regarding preparing ethical committee application, presenting a poster in a congress, submitting a manuscript to a journal, and published research manuscript, a statistically significant difference was observed between residents by the clinics, in which they received training $(\mathrm{p}=0.008, \mathrm{p}<0.001, \mathrm{p}=0.026, \mathrm{p}=0.009$, and $\mathrm{p}=0.003$, respectively). Examining the data by seniority, it can be seen 
that those having seniority of or higher than 24 months participated in most of the items related with playing a role in scientific activities (Table 2). Comparison of the attitudes of ENT residents to the scientific research by gender, type

Table 1. Residents' characteristics

\begin{tabular}{ll}
\hline Variables & $(\mathbf{n}=119)$ \\
\hline Age (years) & $28.2 \pm 1.8$ \\
\hline Gender & \\
\hline Female & $35(29.4 \%)$ \\
\hline Male & $84(70.6 \%)$ \\
\hline Type of hospital & \\
\hline University hospital & $68(57.1 \%)$ \\
\hline Training and research hospital & $51(42.9 \%)$ \\
\hline Residency training periods (years) & $2.2 \pm 1.4$
\end{tabular}

of hospital, and residency training periods is presented in Table 3. The effects of having a structured scientific research education in residency training and having a journal club on regular basis on the participation of residents in scientific activities are statistically presented in Table 4.

\section{Discussion}

The objectives of "research education" are to promote evidence-based medicine practice, to provide skills for lifelong learning, and to support critical-thinking skills. These objectives are in corroboration with the "journal club" activity $(9,10)$. Besides keeping the knowledge on education activity updated, the other objectives of the journal clubs are to provide critical thinking skills and evidence-based practice skills, life-long learning, determining the subjects to research in literature, learning the research methods, to provide the skills of research planning and manuscript writing, and to learn bio-statistical analysis methods (11). Research

Table 2. Comparison of research experience of residents by gender, type of hospital and residency training periods

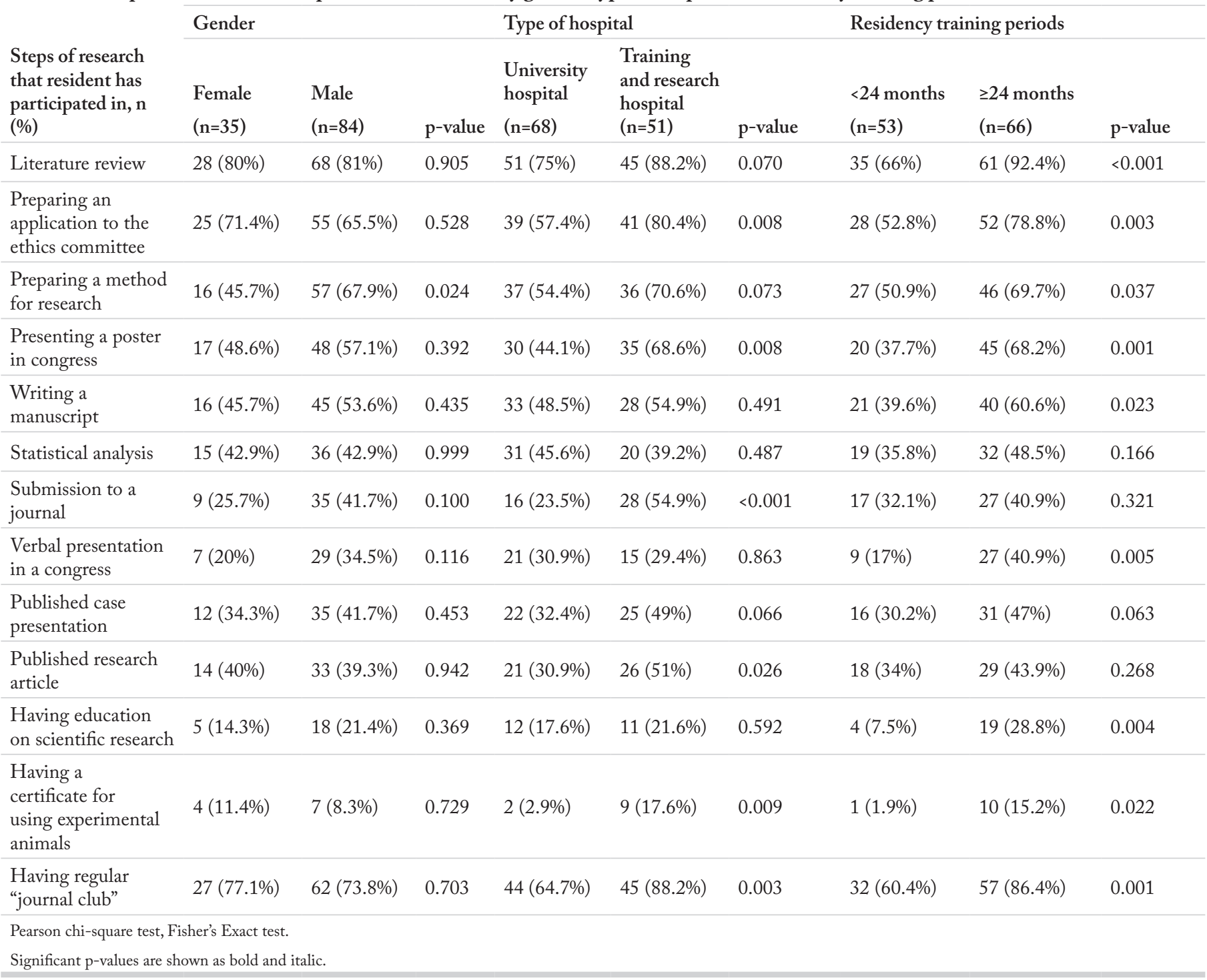


Table 3. Comparison of the attitudes of ENT residents to the scientific research by gender, type of hospital and residency training periods

\begin{tabular}{|c|c|c|c|c|c|c|c|c|c|}
\hline \multirow[b]{2}{*}{$\begin{array}{l}\text { Residents' attitudes } \\
\text { regarding research } \\
\text { experience, mean } \pm \text { SD }\end{array}$} & \multicolumn{3}{|l|}{ Gender } & \multicolumn{3}{|c|}{ Type of hospital } & \multicolumn{3}{|c|}{ Residency training periods } \\
\hline & $\begin{array}{l}\text { Female } \\
(n=35)\end{array}$ & $\begin{array}{l}\text { Male } \\
(n=84)\end{array}$ & $\mathrm{p}$-value & $\begin{array}{l}\text { University } \\
\text { hospital } \\
(n=68)\end{array}$ & $\begin{array}{l}\text { Training } \\
\text { and research } \\
\text { hospital } \\
(\mathrm{n}=51)\end{array}$ & $\mathrm{p}$-value & $\begin{array}{l}<24 \text { months } \\
(n=53)\end{array}$ & $\begin{array}{l}\geq 24 \text { months } \\
(n=66)\end{array}$ & $\mathrm{p}$-value \\
\hline $\begin{array}{l}\text { Every resident should be } \\
\text { given an education on doing } \\
\text { scientific research }\end{array}$ & $4.7 \pm 0.6$ & $4.6 \pm 0.8$ & 0.430 & $4.6 \pm 0.7$ & $4.6 \pm 0.7$ & 0.581 & $4.6 \pm 0.8$ & $4.6 \pm 0.7$ & 0.986 \\
\hline $\begin{array}{l}\text { The education on scientific } \\
\text { research should be given only } \\
\text { to the residents planning to } \\
\text { have an academic career }\end{array}$ & $2.2 \pm 1.4$ & $2.6 \pm 1.7$ & 0.237 & $2.6 \pm 1.6$ & $2.3 \pm 1.6$ & 0.227 & $2.6 \pm 1.7$ & $2.4 \pm 1.5$ & 0.446 \\
\hline $\begin{array}{l}\text { I'd like to participate in } \\
\text { scientific research activities } \\
\text { during my residency time }\end{array}$ & $4.7 \pm 0.6$ & $4.5 \pm 0.8$ & 0.115 & $4.4 \pm 0.8$ & $4.7 \pm 0.6$ & 0.012 & $4.5 \pm 0.7$ & $4.6 \pm 0.8$ & 0.538 \\
\hline $\begin{array}{l}\text { In the clinic, in which I'm } \\
\text { having education, residents } \\
\text { are not given any task in } \\
\text { researches }\end{array}$ & $1.8 \pm 1.3$ & $2.2 \pm 1.4$ & 0.235 & $1.8 \pm 1.2$ & $2.4 \pm 1.5$ & 0.034 & $1.9 \pm 1.2$ & $2.2 \pm 1.5$ & 0.273 \\
\hline $\begin{array}{l}\text { We do not have time for } \\
\text { research }\end{array}$ & $3.2 \pm 1.4$ & $3.5 \pm 1.3$ & 0.335 & $3.3 \pm 1.4$ & $3.4 \pm 1.2$ & 0.692 & $3.4 \pm 1.3$ & $3.4 \pm 1.3$ & 0.892 \\
\hline $\begin{array}{l}\text { I have no knowledge about } \\
\text { counseling to a statistician } \\
\text { for statistical analysis }\end{array}$ & $3.9 \pm 1.2$ & $3.7 \pm 1.4$ & 0.416 & $3.8 \pm 1.2$ & $3.6 \pm 1.5$ & 0.331 & $4.2 \pm 1.1$ & $3.3 \pm 1.4$ & $<0.001$ \\
\hline $\begin{array}{l}\text { My educational background } \\
\text { on research methodology is } \\
\text { not sufficient }\end{array}$ & $4.1 \pm 1.3$ & $4 \pm 1.1$ & 0.573 & $3.9 \pm 1.2$ & $4.2 \pm 1$ & 0.232 & $4.2 \pm 1.2$ & $4 \pm 1.1$ & 0.395 \\
\hline $\begin{array}{l}\text { I do not want to do a } \\
\text { scientific research }\end{array}$ & $1.5 \pm 0.7$ & $1.9 \pm 1.3$ & 0.053 & $2 \pm 1.3$ & $1.5 \pm 0.9$ & 0.024 & $1.7 \pm 1$ & $1.8 \pm 1.2$ & 0.805 \\
\hline $\begin{array}{l}\text { It is very hard to collect data } \\
\text { for a scientific research }\end{array}$ & $2.9 \pm 1.1$ & $2.6 \pm 1.2$ & 0.166 & $2.8 \pm 1.2$ & $2.4 \pm 1.2$ & 0.048 & $2.7 \pm 0.9$ & $2.6 \pm 1.3$ & 0.487 \\
\hline $\begin{array}{l}\text { Data entry for research is an } \\
\text { annoying task }\end{array}$ & $3.2 \pm 1.4$ & $3.3 \pm 1.2$ & 0.775 & $3.3 \pm 1.2$ & $3.2 \pm 1.3$ & 0.680 & $3.3 \pm 1.2$ & $3.2 \pm 1.3$ & 0.927 \\
\hline $\begin{array}{l}\text { It's hard to find financial } \\
\text { support for scientific } \\
\text { researches }\end{array}$ & $4 \pm 1.1$ & $4.3 \pm 0.8$ & 0.149 & $4.1 \pm 1$ & $4.3 \pm 0.8$ & 0.187 & $4.1 \pm 1$ & $4.2 \pm 0.9$ & 0.449 \\
\hline $\begin{array}{l}\text { There is no incentive or } \\
\text { reward for me to participate } \\
\text { in researches }\end{array}$ & $3.6 \pm 1.3$ & $4.1 \pm 1.1$ & 0.058 & $3.8 \pm 1.2$ & $4.1 \pm 1$ & 0.155 & $3.8 \pm 1.2$ & $4 \pm 1$ & 0.387 \\
\hline $\begin{array}{l}\text { There is no guiding } \\
\text { educators leading the way for } \\
\text { participating in researches }\end{array}$ & $2.7 \pm 1.3$ & $2.9 \pm 1.5$ & 0.492 & $2.9 \pm 1.4$ & $2.9 \pm 1.5$ & 0.999 & $2.9 \pm 1.5$ & $2.9 \pm 1.4$ & 0.976 \\
\hline $\begin{array}{l}\text { It should be obligatory for } \\
\text { residents to participate in } \\
\text { researches }\end{array}$ & $3.4 \pm 1.5$ & $3.4 \pm 1.4$ & 0.934 & $3.1 \pm 1.5$ & $3.8 \pm 1.2$ & 0.004 & $3.3 \pm 1.5$ & $3.5 \pm 1.4$ & 0.624 \\
\hline $\begin{array}{l}\text { I do not have opportunity to } \\
\text { access to full texts of research } \\
\text { articles }\end{array}$ & $2.5 \pm 1.5$ & $2.1 \pm 1.3$ & 0.193 & $2.4 \pm 1.3$ & $2 \pm 1.4$ & 0.100 & $2.2 \pm 1.2$ & $2.3 \pm 1.5$ & 0.838 \\
\hline $\begin{array}{l}\text { "Even" the residency thesis is } \\
\text { unnecessary }\end{array}$ & $1.5 \pm 0.9$ & $1.8 \pm 1.1$ & 0.199 & $1.9 \pm 1.2$ & $1.5 \pm 0.7$ & 0.028 & $1.4 \pm 0.8$ & $1.9 \pm 1.2$ & 0.018 \\
\hline $\begin{array}{l}\text { My foreign language is } \\
\text { insufficient for reading and } \\
\text { writing scientific articles }\end{array}$ & $3.1 \pm 1.2$ & $2.8 \pm 1.3$ & 0.311 & $2.9 \pm 1.4$ & $2.9 \pm 1.2$ & 0.903 & $3.1 \pm 1.3$ & $2.7 \pm 1.3$ & 0.140 \\
\hline
\end{tabular}


Table 4. Comparison of research experience of residents by having education on scientific research and regular "journal club" activity

\begin{tabular}{|c|c|c|c|c|c|c|c|c|c|}
\hline \multirow[b]{2}{*}{$\begin{array}{l}\text { Steps of research that resident has } \\
\text { participated in, } \mathrm{n}(\%)\end{array}$} & \multicolumn{3}{|c|}{$\begin{array}{l}\text { Having education on scientific } \\
\text { research }\end{array}$} & \multicolumn{3}{|c|}{$\begin{array}{l}\text { Having a certificate for using } \\
\text { experimental animals }\end{array}$} & \multicolumn{3}{|c|}{$\begin{array}{l}\text { Having regular } \\
\text { "journal club” }\end{array}$} \\
\hline & $\begin{array}{l}\text { Yes } \\
(n=23)\end{array}$ & $\begin{array}{l}\text { No } \\
(n=96)\end{array}$ & $\mathrm{p}$-value & $\begin{array}{l}\text { Yes } \\
(n=11)\end{array}$ & $\begin{array}{l}\text { No } \\
(n=108)\end{array}$ & $\mathrm{p}$-value & $\begin{array}{l}\text { Yes } \\
(\mathrm{n}=89)\end{array}$ & $\begin{array}{l}\text { No } \\
(n=30)\end{array}$ & p-value \\
\hline Literature review & $22(95.7 \%)$ & $74(77.1 \%)$ & 0.043 & $10(90.9 \%)$ & $86(79.6 \%)$ & 0.367 & $77(86.5 \%)$ & $\begin{array}{l}19 \\
(63.3 \%)\end{array}$ & 0.005 \\
\hline $\begin{array}{l}\text { Preparing an application to the } \\
\text { ethics committee }\end{array}$ & $23(100 \%)$ & $57(59.4 \%)$ & $<0.001$ & $11(100 \%)$ & $69(63.9 \%)$ & 0.015 & $65(73 \%)$ & $15(50 \%)$ & 0.020 \\
\hline Preparing a method for research & $18(78.3 \%)$ & $55(57.3 \%)$ & 0.064 & $9(81.8 \%)$ & $64(59.3 \%)$ & 0.199 & $61(68.5 \%)$ & $12(40 \%)$ & 0.006 \\
\hline Presenting a poster in congress & $17(73.9 \%)$ & $48(50 \%)$ & 0.039 & $11(100 \%)$ & $54(50 \%)$ & 0.001 & $54(60.7 \%)$ & $\begin{array}{l}11 \\
(36.7 \%)\end{array}$ & 0.022 \\
\hline Writing a manuscript & $18(78.3 \%)$ & $43(44.8 \%)$ & 0.004 & $8(72.7 \%)$ & $53(49.1 \%)$ & 0.135 & $52(58.4 \%)$ & $9(30 \%)$ & 0.007 \\
\hline Statistical analysis & $17(73.9 \%)$ & $34(35.4 \%)$ & 0.001 & $5(45.5 \%)$ & $46(42.6 \%)$ & 0.999 & $41(46.1 \%)$ & $\begin{array}{l}10 \\
(33.3 \%)\end{array}$ & 0.223 \\
\hline Submission to a journal & $13(56.5 \%)$ & $31(32.3 \%)$ & 0.031 & $6(54.5 \%)$ & $38(35.2 \%)$ & 0.325 & $38(42.7 \%)$ & $6(20 \%)$ & 0.026 \\
\hline Verbal presentation in a congress & $10(43.5 \%)$ & $26(27.1 \%)$ & 0.124 & $3(27.3 \%)$ & $33(30.6 \%)$ & 0.999 & $29(32.6 \%)$ & $7(23.3 \%)$ & 0.340 \\
\hline Published case presentation & $15(65.2 \%)$ & $32(33.3 \%)$ & 0.005 & $7(63.6 \%)$ & $40(37 \%)$ & 0.110 & $39(43.8 \%)$ & $8(26.7 \%)$ & 0.096 \\
\hline Published research article & $14(60.9 \%)$ & $33(34.4 \%)$ & 0.020 & $8(72.7 \%)$ & $39(36.1 \%)$ & 0.024 & $40(44.9 \%)$ & $7(23.3 \%)$ & 0.036 \\
\hline \multicolumn{10}{|l|}{$\begin{array}{l}\text { Pearson chi-square test, Fisher's Exact test. } \\
\text { Significant n-values are shown as bold and it }\end{array}$} \\
\hline
\end{tabular}

education in residency shares such common objectives with the journal club activity. Thus, the journal club is the residents' most important educational activity, in which their research education begins. Besides the common objectives, it was also reported that journal clubs also frequently incorporate the subjects to be investigated (12). The "journal club" is an activity, in which the theoretical background of residents' research education is constructed. It was determined that $76 \%$ of otolaryngology residents participating in the present study have a regular journal club in their clinic. Moreover, it was statistically presented that the residents with regular journal club hours participated in many steps of scientific research projects (Table 4). Thus, it can be stated that the regular journal club activity in residency training of ENT residents increases their participation in research activities.

As in all the surgical branches, also the ENT residency is a tiring and challenging process for the residents (13). Despite this fact, the results of the present study suggest that $89 \%$ of ENT residents wanted to participate in scientific research activities during their residency period. Given this ratio, it can be seen how otolaryngology residents in our country are enthusiastic about this subject. Canadian plastic surgery residents reported the rate of willingness to participate in research to be $70 \%$ (9). The reason for this willingness might be their plans for building an academic career after the residency $(14,15)$. In our country, $40 \%$ of residents plan to build an academic career (16). Although it was not questioned in the present study, the motivation of academic career after the residency might be a factor motivating them to conduct research.

In Turkey, master of science and doctorate programs offer research education, whereas there is no structured formal research education in residency. Otolaryngology residents have already stated that residency should incorporate a formal and structured research education (17). Similarly, the present study showed that $91.6 \%$ of the participants requested research education to be incorporated into the residency program. Moreover, as seen in Table 4, it was determined in the present study that residents having a scientific research training participated in steps of scientific researches more than those having no such training which is statistically significant. This finding corroborates that a training program to be added to ENT residency training would increase the efficiency of students' participation in researches. In Turkey, it is aimed to standardize the residency education by means of the Council of Specialty in Medicine. The best solution would be the integration of research education into the specialty program. However, it cannot be stated that, despite the efforts, no common standards could be achieved in terms of either education centers or educators. However, the scholarly activities of residents should be supported through countrywide activities on research education, in which both residents and educators can participate. Online education programs, in which many residents can participate, can be used in these education programs (18-20). These programs should be planned in the light of science and in guidance of 
experienced specialists in accordance with the principles of educational sciences. Moreover, it should be noted that these educational activities should be financially supported.

In literature, it was reported that, although residents might want to participate in scientific research projects, they may sometimes face several obstacles such as lack of knowledgeskill, insufficient time, and lack of financial support $(14,21)$. The surgical residency educations incorporate an intense study program (13). For this reason, no time can be allocated to scientific research projects and educations while running routine healthcare services. In the present study, the ratio of those accepting the hypothesis "We do not have time for researches" was found to be $45.3 \%$. In previous studies, the most important barrier towards residents' scientific research was reported to be the time factor $(64 \%-78.9 \%)(14,15,21)$. The only solution for the time insufficiency is the research time devoted to scientific research activities in residency programs $(22,23)$. In literature, there is no common practice about how to plan the dedicated research time. There are samples such as research rotation between a year and several months or the activities planned for specific days of a month (5). This time can be determined and planned according to the working conditions of the training clinics and the expectations from the research training. This period can be defined as optional that will not be included in the residency training period.

Another barrier towards residents' scientific research was specified to be the lack of financial support $(21,24)$. In literature, it was reported that $44 \%$ of residents had no sponsors in their scientific studies (24). In the present study, $89 \%$ of participating residents stated that they couldn't access to financial supports. In Turkey, a research designing culture should be established and the financial supports for thesis work, which is one of the requirements of residency programs, should be increased.

Nowadays, because the most common science language is English, incompetence in a foreign language might be an important problem for the residents. In order to do a research and write a manuscript to be published, it is necessary to have a good command of both verbal and written English language. In a study carried out by Y1lmaz et al. (16), it was reported that only $25 \%$ of residents were found to be capable of writing and reading in a foreign language. The results achieved in the present study were in parallel with those reported by Yilmaz et al. It was determined that 36.9\% of participating residents stated that they had no problem in writing and reading in a foreign language, whereas 33.6\% specified it as a problem. For countries, where English is not the native language, such as our country, inefficacy in a foreign language is still considered to be a problem in the education of residents.

Another one among the most important problems in the education of ENT residents was the lack of mentorship to be provided by the educators. During the residency period, mentor should transfer his/her experience in this field, provide guidance at every step, and help with establishing a professional network (25). Residency students should be assigned an active role in every step of research such as guiding to project, preparing a project, and time management, and this can be achieved via mentorship (26). Moreover, another problem is the insufficiency of the mentors $(21,25)$. It was determined that $43.6 \%$ of residents participating in the present study do not agree with the statement "There is no educator guiding me to participate in researches", whereas $21.8 \%$ were neutral. The residents might be thinking so because they witnessed researches at any step in the clinics, in which they were having education. However, in our country, there is no structured research education, which is incorporated in doctorate programs, but not in in residency. Even the academicians giving residency education develop their knowledge on doing research with their own means. The qualifications required for being a researcher have been identified (8). At least, for the academicians participating in residency training, providing structured research and statistics education similar to those in doctorate programs might solve this deficiency.

In the present study, an interesting result on the timing of research training was achieved. In the ENT core curriculum, all the research skills are expected to be achieved in the first half (2). However, at the end of the study, it was determined that the participation of residents in researches increased after the first two years (Table 2). This finding should be considered while updating the ENT core curriculum.

In this study, the experience of residents in research was also questioned. It can be seen in their answers regarding their experiences on the subject that they have participated in almost every step of research process (Table 2). Making a verbal presentation in a congress (30.3\%) was found to be the least frequently performed activity, whereas the most frequently performed one was literature review (80.7\%). Moreover, even the rate of participating in the process of article publication among the participating residents was found to be $39.5 \%$. These results indicate that, even though they haven't received any standard and structured research education, ENT residents in Turkey have somehow participated in research processes. In literature, the rate of lack of interest in research was reported to be $43 \%$ (15). In the present study, the ratio of lack of interest in research was found to be $9.3 \%$. This result indicates how high the interest of ENT residents of our country in this subject is. Other interesting findings of the present study are that 19.3\% of participants have received education in various fields of research, and that $9.2 \%$ of participants have "certificate for using experimental animals". These results show the success and motivations of inquiring students when given an opportunity. 
In our country, residency education is given in university hospitals and research and training hospitals. As a result of this study, it was determined that residents having education in research and training hospitals (51\%) participated in more published research which is statistically significant when compared to those having education in university hospitals (30.9\%) ( $\mathrm{p}=0.026)$. This might be because the participation of residents in researches is supported more in research and training hospitals or because more researches are conducted in training and research hospitals. It is recommended to examine this finding in further studies. From the aspect of gender, a statistically significant difference was found only in the step "Preparing a method for research" and comprehensive qualitative studies are needed to investigate the effects of individual factors.

The individual and mass causes of the factors preventing residents from participating in scientific activities should be investigated in detail. Providing formal scientific research training integrated into residency education would eliminate the lack of education. Allocating time for scientific research in study programs for both educators and residency students can prevent the lack of time and motivate them to participate in scientific research projects. In order to tackle the lack of financial support, which is stated as the most critical barrier in the literature, national measures are needed.

In the present study, the most important limitation is that, although it was aimed to reach 544 ENT residents having education in Turkey, only 119 (21.9\%) residents participated in survey. However, considering the fact that ENT residents at different seniority levels have participated, it can be stated that the results reflect the general residency student population in Turkey. Another limitation is that the present study involves only the results of ENT residents. The attitudes and thoughts about and barriers towards research education among the educators, who are in charge in residency education, should be investigated. The educators should be supported in their inadequacies such as research education and mentorship, etc. For further studies, it is recommended to examine if the residents' scholarly activities allow them to gain critical thinking and evidence-based medical practice skills or, in other words, if the objectives of the educational programs are achieved.

\section{Conclusion}

The otolaryngology residents in Turkey are very eager to have research education and participate in researches. However, residency students may face obstacles such as lack of knowledge-skill, lack of time, or financial support deficiency. The scholarly activities of residents should be supported through countrywide activities on research education, in which both residents and educators playing a role in residency education can participate. Journal club activities should be performed on regular basis and combined with research training.

Ethics Committee Approval: Ethics committee approval was obtained from the Clinical Research Ethics Committee of Pamukkale University (08.01.2020/456).

Informed Consent: Anonymous data were collected via an online survey.

Conflict of Interest: The authors declare no conflict of interest.

Financial Disclosure: The authors declare that they did not receive any financial support during this research and preparation of this study.

\section{Authorship Contributions}

Concept: H.E., C.O.K., Design: H.E., C.O.K., Data Collection and/or Processing: H.E., C.O.K., Analysis and/ or Interpretation: H.E., C.O.K., Writing: H.E., C.O.K., Critical Review: H.E., C.O.K.

\section{Main Points}

- The objectives of education are to promote evidence-based medicine practice, to provide skills for life-long learning, and to support critical-thinking skills.

- The results of the present study suggest that $89 \%$ of ENT residents wanted to participate in scientific research activities during their residency period.

- Journal club activities should be organized on regular basis and integrated with research education.

- The scholarly activities of residents should be supported through countrywide activities on research education, in which both residents and educators playing a role in residency education can participate.

\section{References}

1. Seehusen DA, Weaver SP. Resident research in family medicine: Where are we now? Fam Med 2009; 41: 663-8. [Crossref]

2. Tababet Uzmanllk Yönetmeliği [Regulation for Medicine Specialities in Medicine] (1974) (cited 2021 July). Available at:https://tuk.saglik.gov.tr/Eklenti/13275/0/14893pdf.pdf [Crossref]

3. Turkish ORL-HNS Residency Core Training Program. Turkish ORL-HNS Competency Board 2012 (cited 2021 July). Available at: https://www.kbbyeterlik.org.tr/TKBBBBCYKData/Uploads/ files/ucep.pdf [Crossref]

4. Kulak Burun Boğaz Hastalıkları Uzmanlık Eğitimi Çekirdek Müfredatı (2019). [Turkish ORL-HNS Residency Core Training Program] (cited 2021 July). Available at: https://tuk.saglik.gov.tr/ TR-84694/v-24-dokumanlari.html [Crossref] 
5. Thomas JB, Cofer JB, Lewis PL, Burns RP. Clinical research during surgery residency: the Chattanooga approach Curr Surg 2000; 57: 135-9. [Crossref]

6. Shenoy-Bhangle AS, Eisenberg RL, Fineberg T, Slanetz PJ. Residency mini-fellowships in the PGY-5 year: is there added value? Acad Radiol 2018; 25: 708-13. [Crossref]

7. Hames K, Patlas M, Duszak R. Barriers to resident research in Radiology: a Canadian perspective. Can Assoc Radiol J 2018; 69: 260-5. [Crossref]

8. Verderame MF, Freedman VH, Kozlowski LM, McCormack WT. Competency-based assessment for the training of $\mathrm{PhD}$ students and early-career scientists. Elife 2018; 7: e34801. [Crossref]

9. McLeod P, Steinert Y, Boudreau D, Snell L, Wiseman J. Twelve tips for conducting a medical education journal club. Med Teach 2010; 32: 368-70. [Crossref]

10. Linzer M. The journal club and medical education: over one hundred years of unrecorded history. Postgrad Med J 1987; 63: 475-8. [Crossref]

11. Kara CO, Özdemir S. KBB uzmanlık eğitiminde etkin makale saati uygulaması için öneriler. KBB-Forum 2013; 12: 42-8. [Crossref]

12. Kenton K, Brubaker L. Research education in obstetrics and gynecology: how are we doing? Am J Obstet Gynecol 2007; 197 : 532.e1-4. [Crossref]

13. Dokuzlar U, Miman MC, Denizoğlu İI, Egrilmez M. Opinions of otorhinolaryngology residents about their education process. Turk Arch Otorhinolaryngol 2015; 53: 100-7. [Crossref]

14. Canadian Plastic Surgery Research Collaborative (CPSRC). Barriers and attitudes to research among residents in plastic and reconstructive surgery: a national multicenter cross-sectional study. J Surg Educ 2017; 74: 1094-104. [Crossref]

15. Mansi A, Karam WN, Chaaban MR. Attitudes of residents and program directors towards research in otolaryngology residency. Ann Otol Rhinol Laryngol 2019; 128: 28-35. [Crossref]

16. Yılmaz Y, Uçar E, Ertin H. Tıpta uzmanlık eğitimi ve asistan hekimlerin sorunlarının irdelenmesi: bir anket çalışması. Tıp Eğitimi Dünyası 2019; 18: 21-9. [Crossref]
17. Kara CO, Daloğlu M. KBB Asistan eğitiminde standardizasyon paneli: uzmanlık öğrencileri ve eğiticilerin görüşleri. Tıp Eğitimi Dünyası. 2018; 51: 72-5. [Crossref]

18. Eyigör H, Gürpınar E. A study on the use of massive open online courses in otorhinolaryngology after graduation. Turk Arch Otorhinolaryngol 2019; 57: 171-5. [Crossref]

19. Morbitzer KA, Rao KV, Rhoney DH, Pappas AL, Durr EA, Sultan SM, et al. Implementation of the flipped residency research model to enhance residency research training. Am J Health Syst Pharm 2019; 76: 608-12. [Crossref]

20. Tamariza L, Vasquez D, Loor C, Palacio A. Successful adaptation of a research methods course in South America. Med Educ Online. 2017; 22: 1336418. [Crossref]

21. Fournier I, Stephenson K, Fakhry N, Jia H, Sampathkumar $\mathrm{R}$, Lechien JR, et al. Barriers to research among residents in Otolaryngology -Head \& Neck Surgery around the world. Eur Ann Otorhinolaryngol Head Neck Dis. 2019; 136: S3-S7. [Crossref]

22. Vinci RJ, Bauchner H, Finkelstein J, Newby PK, Muret-Wagstaff $\mathrm{S}$, Lovejoy FH. Research during pediatric residency training: outcome of a senior resident block rotation. Pediatrics 2009; 124: 1126-34. [Crossref]

23. Personett HA, Hammond DA, Frazee EN, Skrupky LP, Johnson TJ, Schramm GE. Road map for research training in the residency learning experience. J Pharm Pract 2018; 31: 489-96. [Crossref]

24. Okera N, Escabasse V, Coste A, Albers AE. ORL residency in France: satisfaction and training quality in 2013. Eur Ann Otorhinolaryngol Head Neck Dis 2015; 132: 327-32. [Crossref]

25. Çoşkun Ö. Mentorluk. Turkiye Klinikleri J Med Educ-Special Topics 2016; 1: 8-15. [Crossref]

26. Öcek Z, Bat1 H, Sezer ED, Köroğlu ÖA, Yılmaz Ö, Y1lmaz ND, et al. Research training program in a Turkish medical school: challenges, barriers and opportunities from the perspectives of the students and faculty members. BMC Med Educ. 2021; 4: 21: 2. [Crossref] 